\begin{tabular}{|c|c|}
\hline \multirow{3}{*}{ 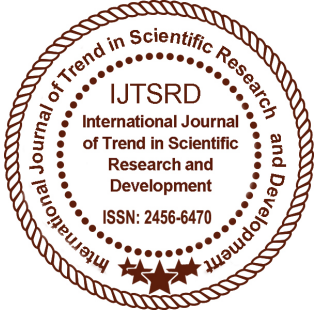 } & $\begin{array}{l}\text { International Journal of Trend in Scientific } \\
\text { Research and Development (IJTSRD) }\end{array}$ \\
\hline & International Open Access Journal \\
\hline & ISSN No: 2456 - 6470 | www.ijtsrd.com | Volume - 2 | Issue - 5 \\
\hline
\end{tabular}

\title{
Spectrophotometric Oxidation Method for the Determination of Teneligliptin by Using Bromate - Bromide Mixture
}

\author{
I. Lakshmi Prasanna ${ }^{1}$, G. T. Naidu ${ }^{1}$, G. Abdul Huq ${ }^{2}$ \\ ${ }^{1}$ Research Scholar, Department of Physics, Rayalaseema University, Kurnool, Andhra Pradesh, India \\ ${ }^{2}$ Department of Chemistry, School of Sciences, Maulana Azad National Urdu University, \\ Hyderabad, Telangana, India
}

\section{ABSTRACT}

A sensitive, precise, accurate, simple and rapid spectrophotometric method has been developed for the estimation of Teneligliptin in pharmaceutical formulations and in the drug dosage form. During the course of study, it is observed that acidic solution of the drug formed the oxidation product with Bromate Bromide mixture. This property of the drug is exploited for the development of spectrophotometric method for the determination and analysis of the drug. The oxidation product showed $\lambda \max$ at $250 \mathrm{~nm}$. The linearity range for Teneligliptin is found to be 10 $\mu \mathrm{g} / \mathrm{ml}$ to $250 \mu \mathrm{g} / \mathrm{ml}$. Recovery studies gave satisfactory results indicating that none of common additives and excipients interfere the assay method. The molar absorptivity and the sandell sensitivity of the method are evaluated and the values are found to be to be $1.1645 \times 104 \mathrm{lit} / \mathrm{mole} / \mathrm{cm}$ and $0.0366 \mu \mathrm{g} /$ $\mathrm{ml} / \mathrm{cm} 2$ respectively.

KEYWORDS: Spectrophotometry, Teneligliptin, Bromate-Bromide oxidant, Pharmaceutical formulations

\section{INTRODUCTION}

A novel class of compounds which revolutionized the treatment of diabetes in the recent past is

Dipeptidylpeptidase-4 (DPP-4) inhibitors which are widely known as Gliptins. Teneligliptin hydrobromide hydrate is a novel, potent peptidomimetric and long acting DPP-4 inhibitor is the approved drug for the treatment of type 2 Diabetes Milletus (T2DM). Teneligliptin is chemically $\{(2 \mathrm{~S}, 4 \mathrm{~S})-4-[4-(3-m e t h y l-$ 1-phenyl-1H-pyrazol-5-yl) piperazin-1-yl] pyrrolidin2-yl\}(1,3-thiazolidin-3-yl) methanone hemipenta bromide hydrate, the structure of which is as shown in Figure 1.

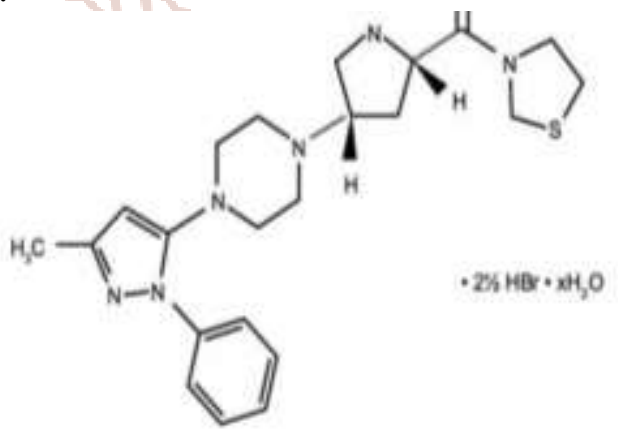

Figure 1: Structure of Teneligliptin

It is a unique structure characterized by five consecutive rings. Recent studies have shown that the drug exhibits multiple pharmaceutical effects which include vasoprotective, neuro protective effects etc. Teneligliptin which inhibits the enzyme DPP-4 and degrades incretin, a hormone which adjusts blood glucose level and improves blood glucose control. A survey of chemical literature has shown that the drug Teneligliptin is effectively used to treat Type 2 diabetes mellitus ${ }^{[1-7]}$ (T2DM). Further it is noticed that only a very few methods on the development and validation for the estimation of Teneligliptin are reported which include UV spectrophotometric methods ${ }^{[8-10]}$ and High Performance Thin Layer Chromatographic (HPTLC) method ${ }^{[10]}$. Since not much attention has been given to develop newer analytical UV spectrophotometric methods for the quantitative determination of such an effective and potential anti diabetic drug in the dosage form and in the pharmaceutical formulations form, the author is prompted to take up this study and develop suitable new, rapid, sensitive, precise and accurate method for 
the determination of Megagliptin. The results obtained in the present investigations are communicated in this paper.

\section{MATERIALS AND METHODS:}

Instrumentation: A single beam spectrophotometer Model SP-UV200 with $1 \mathrm{~cm}$ matched quartz cuvettes is employed throughout the study for all opticometric measurements.

\section{Preparation of Reagents and Solutions:- Teneligliptin solution:}

$50 \mathrm{mg}$ of pure Teneligliptin is dissolved in methanol and the volume of the resulting solution is adjusted to the mark in the $50 \mathrm{ml}$ standard flask with methanol. This is used as the stock solution of the drug. The working solution with concentration $50 \mu \mathrm{g} / \mathrm{ml}$ of the drug is prepared by suitably diluting the stock solution as and when required.

\section{M HCL solution:}

$425 \mathrm{ml}$ of Conc. Hydrochloric acid (Merck) is diluted to $1000 \mathrm{ml}$ with distilled water to get about $5 \mathrm{M}$ Hydrochloric Acid solution.

\section{Bromate - Bromide Mixture preparation:}

$0.835 \mathrm{~g}$ of Potassium Bromate and $6 \mathrm{~g}$ of Potassium Bromide are dissolved in distilled water and diluted to one litre. The solution is appropriately diluted to get $10 \mu \mathrm{g} / \mathrm{ml}$ with respect to Potassium Bromate.

\section{Methyl Orange solution:}

$50 \mathrm{mg}$ of Methyl Orange is dissolved in $50 \mathrm{ml}$ water and is diluted to get $50 \mu \mathrm{g} / \mathrm{ml}$.

All other chemical substances and reagents employed in the present investigations are of AR Grade only.

\section{RESULTS AND DISCUSSION:}

Teneligliptin when treated with Bromate - Bromide mixture with Methyl Orange as an indicator forms an oxidation reaction. This oxidation formation reaction is spectrophotometrically monitored to develop a method for the determination of the drug. In the process of carrying out detailed investigations, first of all, optimisation of various parameters such as the wavelength of maximum absorbance $\left(\lambda_{\max }\right)$, the effect of the concentration of oxidizing agent Bromate Bromide mixture and an indicator Methyl Orange on the absorbance of the oxidation are established and the procedures adopted in each case are described as follows:
Absorption Spectrum of Oxidation reaction:

The absorption spectrum of the oxidation reaction formed between Teneligliptin and Bromate -Bromide mixture is obtained in order to fix the wavelength of maximum absorbance in the present study. The experimental procedure adopted is as follows:

$1 \mathrm{ml}$ of Teneligliptin solution $(50 \mu \mathrm{g} / \mathrm{ml}), 1 \mathrm{ml}$ of $5 \mathrm{M}$ $\mathrm{HCl}, 1 \mathrm{ml}$ of Bromate-Bromide mixture, $1 \mathrm{ml}$ of Methyl Orange $(50 \mu \mathrm{g} / \mathrm{ml})$ is taken in a $10 \mathrm{ml}$ standard flask. The resulting solution is made up to the mark with distilled water. The contents of the flask are shaken well and allowed to stand for a minute for equilibration. Then the absorbance values of the oxidation reaction formed are measured in the wavelength range $190 \mathrm{~nm}$ to $310 \mathrm{~nm}$ against the reagent blank. The results obtained are used to draw a graph between the wavelength and the absorbance values. This graphical representation is called the Absorption spectrum which is shown in figure 2 below.

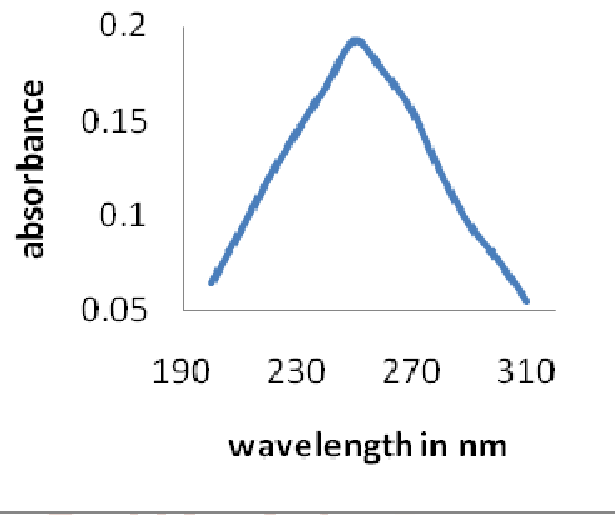

Fig.2: Absorption Spectrum of Oxidation reaction of Teneligliptin with Bromate- Bromide Mixture

It is seen from the above Fig. 2 of the absorption spectrum, that the maximum absorbance is obtained at $250 \mathrm{~nm}$. Hence for all further studies, the wavelength $250 \mathrm{~nm}$ is fixed.

\section{Effect of Bromate-Bromide:}

The effect of Bromate-Bromide mixture on the absorbance of the oxidation reaction is studied by taking varying volumes $(\mathrm{x} \mathrm{ml})$ of Bromate-Bromide in a series of $10 \mathrm{ml}$ standard flasks. After taking $\mathrm{x} \mathrm{ml}$ $(0.5 \mathrm{ml}$ to $2.5 \mathrm{ml})$ of Bromate-Bromide mixture in each flask, $1 \mathrm{ml}$ of $5 \mathrm{M} \mathrm{HCl}, 1 \mathrm{ml}$ of drug solution of Teneligliptin, $1 \mathrm{ml}$ of Methyl Orange $(50 \mu \mathrm{g} / \mathrm{ml})$ are added and the resulting solution is made up to $10 \mathrm{ml}$ using distilled water. The absorbance of each solution is recorded at $250 \mathrm{~nm}$ against a suitable blank and is as shown in Table 1 below. 


\section{Table 1: Effect of Bromate-Bromide on Oxidation}

$1 \mathrm{ml}$ Teneligliptin $(50 \mu \mathrm{g} / \mathrm{ml})+\mathrm{x} \mathrm{ml}(0.5 \mathrm{ml}$ to $2.5 \mathrm{ml})$ of Bromate-Bromide mixture solution $(10 \mu \mathrm{g} / \mathrm{ml})+1 \mathrm{ml}$ of Methyl Orange solution $(50 \mu \mathrm{g} / \mathrm{ml})+1 \mathrm{ml}$ of $5 \mathrm{M} \mathrm{HCl}+(7-\mathrm{x}) \mathrm{ml}$ distilled water $=$ Total volume kept at 10 ml each.

$\lambda_{\max }=250 \mathrm{~nm}$.

\begin{tabular}{|c|c|c|c|c|c|c|c|}
\hline $\begin{array}{c}\text { S. } \\
\text { No }\end{array}$ & $\begin{array}{c}\text { Vol. of } \\
\text { Teneligliptin (50 } \\
\mu \mathrm{g} / \mathrm{ml}) \text { in } \mathrm{ml}\end{array}$ & $\begin{array}{c}\text { Vol. of Bromate- } \\
\text { Bromide Solution } \\
(10 \mu \mathrm{g} / \mathrm{ml}) \times \mathrm{ml}\end{array}$ & $\begin{array}{c}\text { Vol. of } \\
\text { Methyl } \\
\text { Orange (50 } \\
\mu \mathrm{g} / \mathrm{ml}) \text { in } \mathrm{ml}\end{array}$ & $\begin{array}{c}\text { Vol. } \\
\text { of } 5 \mathrm{M} \\
\mathrm{HCl}\end{array}$ & $\begin{array}{c}\text { Vol. of } \\
\text { distilled } \\
\text { water in } \mathrm{ml} \\
(7-\mathrm{x})\end{array}$ & $\begin{array}{l}\text { Total vol. } \\
\text { in each } \\
\text { flask in } \\
\mathrm{ml}\end{array}$ & $\begin{array}{c}\text { Absorb } \\
\text {-ance }\end{array}$ \\
\hline 1 & 1.0 & 0.5 & 1.0 & 1.0 & 6.5 & 10 & 0.056 \\
\hline 2 & 1.0 & 1.0 & 1.0 & 1.0 & 6.0 & 10 & 0.094 \\
\hline 3 & 1.0 & 1.5 & 1.0 & 1.0 & 5.5 & 10 & 0.107 \\
\hline 4 & 1.0 & 2.0 & 1.0 & 1.0 & 5.0 & 10 & 0.118 \\
\hline 5 & 1.0 & 2.5 & 1.0 & 1.0 & 4.5 & 10 & 0.101 \\
\hline
\end{tabular}

It is observed that $2 \mathrm{ml}$ of Bromate-Bromide mixture solution is required for maximum absorbance. Hence for all further studies a volume of $2 \mathrm{ml}$ of Bromate-Bromide mixture solution is fixed.

\section{Effect of volume of Methyl Orange:}

The effect of Methyl Orange on the absorbance of oxidation is studied by taking varying volumes of (x ml) of Methyl orange solution in a series of $10 \mathrm{ml}$ standard flasks keeping the volume of Teneligliptin solution fixed at $1 \mathrm{ml}$. To each flask $1 \mathrm{ml}$ of $5 \mathrm{M} \mathrm{HCl}$ and $2 \mathrm{ml}$ of Bromate-Bromide mixture solution are added followed by the addition of distilled water to make up each $10 \mathrm{ml}$ flask to mark. The absorbance of each solution is recorded at $250 \mathrm{~nm}$ against the suitable blank and is as shown in Table 2 below.

\section{Table 2: Effect of Methyl Orange on Oxidation}

$1 \mathrm{ml}$ Teneligliptin $(50 \mu \mathrm{g} / \mathrm{ml})+\mathrm{x} \mathrm{ml}(0.5 \mathrm{ml}$ to $2.5 \mathrm{ml})$ of Methyl Orange solution $(50 \mu \mathrm{g} / \mathrm{ml})+2 \mathrm{ml} \mathrm{of}$ Bromate-Bromide mixture solution $(10 \mu \mathrm{g} / \mathrm{ml})+1 \mathrm{ml}$ of $5 \mathrm{M} \mathrm{HCl}+(6-\mathrm{x}) \mathrm{ml}$ distilled water $=$ Total volume kept at $10 \mathrm{ml}$ each.

$\lambda_{\max }=250 \mathrm{~nm}$.

\begin{tabular}{|c|c|c|c|c|c|c|c|}
\hline $\begin{array}{l}\text { S. } \\
\text { No }\end{array}$ & $\begin{array}{c}\text { Vol. of } \\
\text { Teneliglipt-in(50 } \\
\mu \mathrm{g} / \mathrm{ml}) \text { in } \mathrm{ml}\end{array}$ & $\begin{array}{c}\text { Vol. of } \\
\text { Methyl } \\
\text { Ora } \\
\text {-nge solu } \\
\text {-tion }(50 \\
\text { ug/ml) } \mathrm{x} \\
\mathrm{ml}\end{array}$ & $\begin{array}{c}\text { Vol. of Bromate } \\
\text { Bromide } \\
\text { (10 } \mu \mathrm{g} / \mathrm{ml}) \text { in } \mathrm{ml}\end{array}$ & $\begin{array}{l}\text { Vol.of } \\
5 \mathrm{M} \mathrm{HCl} \\
\text { in } \mathrm{ml}\end{array}$ & $\begin{array}{l}\text { Vol. of } \\
\text { distilled } \\
\text { water in } \\
\text { ml(6-x) }\end{array}$ & $\begin{array}{l}\text { Total vol. } \\
\text { in each } \\
\text { flask in } \\
\text { ml }\end{array}$ & $\begin{array}{c}\text { Absorb } \\
\text {-ance }\end{array}$ \\
\hline 1 & 1.0 & 0.5 & $\begin{array}{r}-2.0 \\
\end{array}$ & 1.0 & 5.5 & 10 & 0.038 \\
\hline 2 & 1.0 & 1.0 & 2.0 & 1.0 & 5.0 & 10 & 0.065 \\
\hline 3 & 1.0 & 1.5 & 2.0 & 1.0 & 4.5 & 10 & 0.047 \\
\hline 4 & 1.0 & 2.0 & 2.0 & 1.0 & 4.0 & 10 & 0.043 \\
\hline 5 & 1.0 & 2.5 & 2.0 & 1.0 & 3.5 & 10 & 0.063 \\
\hline
\end{tabular}

It is observed that $1.0 \mathrm{ml}$ of Methyl Orange solution is necessary to achieve maximum absorbance. Hence for all further studies a volume of $1.0 \mathrm{ml}$ of Methyl Orange solution is required.

\section{Effect of concentration of Drug Teneligliptin:}

This study pertains to the effect of the drug Teneligliptin concentration on the absorbance of the Oxidation reaction under the established optimal experimental conditions. The recommended procedure for the calibration curve and for the obedience of Beer-Lambert's Law for the quantitative spectrophotometric determination of the drug Teneligliptin is as follows.

\section{Calibration Curve: Obedience of Beer - Lambert's Law:}


Various aliquots (x ml i.e., $0.5 \mathrm{ml}$ to $2.5 \mathrm{ml}$ ) of Teneligliptin solution $(50 \mu \mathrm{g} / \mathrm{ml})$ are taken in a series of $10 \mathrm{ml}$ standard flask. To each flask, $1.0 \mathrm{ml}$ of Methyl Orange solution, $2.0 \mathrm{ml}$ of Bromate-Bromide mixture solution, $1 \mathrm{ml}$ of $5 \mathrm{M} \mathrm{HCl}$ are added followed by $(6-\mathrm{x}) \mathrm{ml}$ of distilled water are added so as to make the total volume in each case at $10 \mathrm{ml}$. The contents of each flask are shaken well and allowed to stand for a minute for equilibration. The absorbance of each solution is measured at $250 \mathrm{~nm}$ against a suitable reagent blank which is prepared in a similar manner but devoid of drug solution and is as shown in Table 3 below.

\section{Table 3: Calibration Curve - Obedience of Beer- Lambert's Law}

$\mathrm{x} \mathrm{ml}$ of Teneligliptin $(50 \mu \mathrm{g} / \mathrm{ml})+1 \mathrm{ml}$ of Methyl Orange solution $(50 \mu \mathrm{g} / \mathrm{ml})+2 \mathrm{ml}$ of Bromate-Bromide mixture solution $(10 \mu \mathrm{g} / \mathrm{ml})+1 \mathrm{ml}$ of $5 \mathrm{M} \mathrm{HCl}+(6-\mathrm{x}) \mathrm{ml}$ distilled water $=$ Total volume kept at $10 \mathrm{ml}$ each. $\lambda_{\max }=250 \mathrm{~nm}$.

\begin{tabular}{|c|c|c|c|c|c|c|c|c|}
\hline $\begin{array}{c}\text { S.N } \\
\mathbf{0}\end{array}$ & $\begin{array}{c}\text { Vol. in ml } \\
\text { Teneligliptin } \\
(50 \mu \mathrm{g} / \mathrm{ml}) \mathrm{x} \\
\mathrm{ml}\end{array}$ & $\begin{array}{c}\text { Amount of } \\
\text { Teneligliptin in } \\
\mu \mathrm{g} / \mathrm{ml}\end{array}$ & \begin{tabular}{|c|} 
Vol. of \\
Methyl \\
Orange \\
$(50 \mu \mathrm{gg} / \mathrm{ml})$ \\
in $\mathrm{ml}$
\end{tabular} & $\begin{array}{c}\text { Vol. of } \\
\text { Bromate- } \\
\text { Bromide } \\
(10 \mu \mathrm{g} / \mathrm{ml}) \\
\text { in } \mathrm{ml} \\
\end{array}$ & 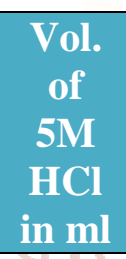 & $\begin{array}{l}\text { Vol. of } \\
\text { distilled } \\
\text { water in } \\
\mathrm{ml}(6-\mathbf{x})\end{array}$ & $\begin{array}{l}\text { Total } \\
\text { vol.in } \\
\text { each } \\
\text { flask in } \\
\text { ml } \\
\end{array}$ & $\begin{array}{c}\text { Abso } \\
\text { rb } \\
\text {-ance }\end{array}$ \\
\hline 1 & 0.5 & 50 & 11.0 & 2.0 & 1.0 & 5.5 & 10 & 0.067 \\
\hline 2 & 1.0 & & 1.0 & 2.0 & 1.0 & 5.0 & 10 & 0.115 \\
\hline 3 & 1.5 & 150 & 1.0 & 2.0 & 1.0 & 4.5 & 10 & 0.163 \\
\hline 4 & 2.0 & 200 & 1.0 & 2.0 & 1.0 & 4.0 & 10 & 0.212 \\
\hline 5 & 2.5 & 250 & Elr 1.0 & al 2.0 & 1.0 & 3.5 & 10 & 0.273 \\
\hline
\end{tabular}

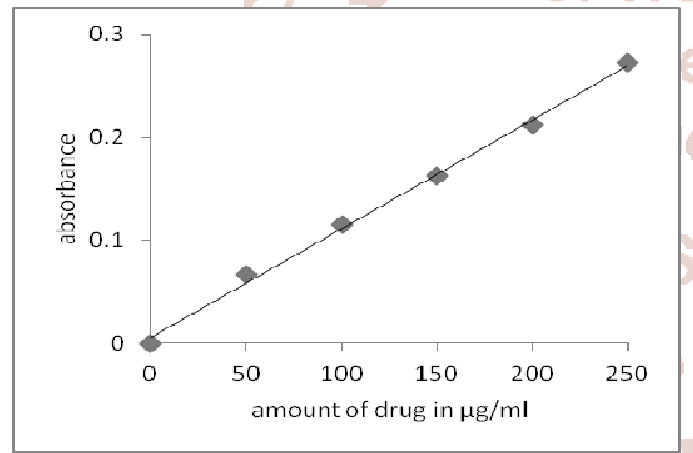

Fig.3 Calibration curve -Verification of BeerLambert's Law

It is obviously clear from this calibration straight line as shown in above Fig.3 that the absorbance values increased linearly with the increase in the amount of the drug. This verifies the Beer-Lambert's Law and suggests that the method can be successfully employed for the spectrophotometric quantitative determination of the drug Teneligliptin in the range 10 $\mu \mathrm{g} / \mathrm{ml}$ to $250 \mu \mathrm{g} / \mathrm{ml}$. The molar absorptivitiy and the Sandell Sensitivity of the method are found to be $1.1645 \times 10^{4}$ lit/ mole/cm and $0.0366 \mu \mathrm{g} / \mathrm{ml} / \mathrm{cm}^{2}$ respectively.
Assay of Teneligliptin drug in pharmaceutical formulations: -

The recommended procedure for the quantitative micro determination of Teneligliptin drug is applied for the assay of the drug in the dosage form of the commercial tablets and also in pharmaceutical formulations. The assay is carried out as follows:

20 tablets of Teneligliptin are weighed and finely powdered. An accurately weighed portion of the powdered sample equivalent to $50 \mathrm{mg}$ of Teneligliptin is taken in a $50 \mathrm{ml}$ volumetric flask containing $25 \mathrm{ml}$ of methanol and is sonicated for about 20 minutes. The resultant solution is filtered through Whatman filter paper No.41 into another $50 \mathrm{ml}$ volumetric flask. The filter paper is washed several times with methanol and the washings are added to filtrate. The final volume is made upto the mark with methanol. Now, $5 \mathrm{ml}$ of filtrate of the sample solution is diluted to $10 \mathrm{ml}$ with methanol and treated as per the recommended procedure of calibration. From this, the amount of the drug present in the sample is computed from the calibration curve. The results obtained are as shown in Table 4 below. 
International Journal of Trend in Scientific Research and Development (IJTSRD) ISSN: 2456-6470

Table 4: Assay of Teneligliptin in Tablets

\begin{tabular}{|c|c|c|c|c|c|}
\hline Sample & $\begin{array}{c}\text { Labelled amount } \\
\text { in mg }\end{array}$ & $\begin{array}{c}\text { Amount found by present } \\
\text { method } \pm \text { SD }\end{array}$ & $\begin{array}{c}\text { Percentage of Label } \\
\text { claim }\end{array}$ & $*_{\text {cal }}$ & $\begin{array}{c}\% \\
\text { RSD }\end{array}$ \\
\hline Tablet I & 20 & $20.032 \pm 0.13$ & 100.032 & 0.5351 & 0.6681 \\
\hline Tablet II & 20 & $20.022 \pm 0.12$ & 100.022 & 0.3977 & 0.6180 \\
\hline
\end{tabular}

* Average of 5 determinations based on label claim.

\section{CONCLUSION:}

The calibration curve is linear up to $250 \mu \mathrm{g} / \mathrm{ml}$ indicating the suitability of the proposed method for the spectrophotometric determination of Teneligliptin in the range of $10 \mu \mathrm{g} / \mathrm{ml}$ to $250 \mu \mathrm{g} / \mathrm{ml}$. The standard deviation values are found to be low showing high accuracy and reproducibility of the method. The calculated ' $t$ ' values are less than the ' $t$ ' theoretical values with 4 degrees of freedom at $95 \%$ level of significance. This indicates that there is no significant difference between the proposed method and the standard method. Further, there is no effect of additives and excipients such as starch, calcium lactose and glucose in the concentration of those present in general pharmaceutical preparations. Thus the proposed method can be conveniently adopted for the routine analysis of estimation of Teneligliptin in pharmaceutical formulations.

\section{ACKNOWLEDGEMENTS:}

The author (ILP) expresses her grateful thanks to the authorities of the Departments of Physics and Chemistry of Rayalaseema University, Kurnool, the Central Instrumentation Cell of Prof. T Jayashankar Telangana State Agricultural University, Hyderabad for providing necessary facilities.

\section{REFERENCES:}

1. Hiroaki U, Eiichiro Y, Chikako T. Teneligliptin improves glycemic control with the reduction of postprandial insulin requirement in Japanese diabetic patient, Endocrine Journal 2015; 62(1): 13-20.

2. Miyako K. Teneligliptin: A DPP4 inhibitor for the treatment of type 2 diabetes, Dove Medical Press 2013; 6: 187-195.

3. Ryuichi M, Hironori N. Teneligliptin: expectations for its pleiotropic action. Expert Opinion on Pharmacotherapy 2015; 16(3): 417426.

4. Yoshida T, Sakishima H, Akahoshi F et al. Discovery and preclinical profile of Teneligliptin (3-[(2S,4S)-4-[4(3-methyl-1-phenyl-1H-pyrazole5-yl)piperazin-1-yl]pyrrolidone-2-ylcarbonyl]thiazolidine) : A highly potent, selective, long-lasting and orally active dipeptidyl peptidase IV inhibitor for the treatment of type 2 diabetes. Bio-org Med Chem. 2012 Oct 01; 20(19): 5705-5719.

5. Eto T, Inoue S, Kadowaki T. Effects of once-daily Teneligliptin on 24-h blood glucose control and safety in Japanese patients with type 2 diabetes mellitus: a 4-week, randomized, double-blind, placebo-controlled trial. Diabetes ObesMetab. 2012 Nov; 14(11):1040-6.

6. Fukuda-Tsuru S, Anabuki J, Abe Y et al. A novel, potent and long-lasting dipeptidyl peptidase-4 inhibitor, Teneligliptin, improves postprandial hyperglycemia and dyslipidemia after single and repeated administrations. Eur J Pharmacol. 2012 Sep 26. pii: S0014-2999(12)00798-4. doi: 10.1016/j.ejphar.2012.09.024.

7. Kishimoto $\mathrm{M}$ et al, DOI: http://dx.doi.org/10.2147/DMSO.S35682,Publishe d Date May 2013 Volume 2013:6 Pages 187 195).

8. Mr. Amit M. Sonawane et al. A Simple UV Spectrophotometric Method Development and Validation of Teneligliptin in Tablet Dosage Form Indo American Journal of Pharmaceutical Research.2016 : 6 (04).

9. Sen AK, Hinsu DN, Sen DB, Zanwar AS, Maheshwari RA, Chandrakar VR. Analytical method development and validation for simultaneous estimation of Teneligliptin hydro bromide hydrate and Metformin hydrochloride from its pharmaceutical dosage form by three different UV spectrophotometric methods. J App Pharm Sci, 2016; 6 (09): 157-165.

10. 10. Job, P. Ann. Chim. (1928) 9, 113-203.

11. Vishnu C. Shinde, Kiran B. Aher, Girija B. Bhavar, Sachin J. Kakad and Sanjay R. Chaudhari. Development and validation of UV spectrophotometric method and high performance thin layer chromatographic (HPTLC) method for estimation of Teneligliptin hydro bromide in pharmaceutical preparation. Department of Quality Assurance Techniques, Amrutvahini College of Pharmacy, Sangamner, Maharashtra, India Der Pharmacia Lettre, 2016, 8 (8):291-301. 